\title{
Arbuscular mycorrhizal soil infectivity in a stand of the wetland tree Pterocarpus officinalis along a salinity gradient
}

\author{
L. Saint-Etienne ${ }^{\text {a }}$, S. Paul ${ }^{\text {a }}$, D. Imbert ${ }^{\text {a }}$, M. Dulormne ${ }^{\text {a }}$, F. Muller ${ }^{\text {a }}$, \\ A. Toribio ${ }^{\mathrm{b}}$, C. Plenchette ${ }^{\mathrm{c}, *}$, A.M. Bâ ${ }^{\mathrm{a}}$ \\ a Laboratoire de Biologie et Physiologie Végétales, UFR Sciences Exactes et Naturelles, Université des Antilles et de la Guyane, \\ BP. 592, 97159 Pointe-à-Pitre, Guadeloupe, France \\ ${ }^{\mathrm{b}}$ Laboratoire de Mycologie-Flore Pathogène du Sol, URPV, Domaine de Duclos, INRA centre Antilles-Guyane, \\ F-97170 Petit-Bourg, Guadeloupe, France \\ ${ }^{\mathrm{c}}$ Environment et Agronomie, UMR BGA, Institut National de la Recherche Agronomique, INRA, \\ 17 rue Sully, 21065 Dijon Cedex, France
}

Received 13 December 2005; received in revised form 24 April 2006; accepted 17 May 2006

\begin{abstract}
Pterocarpus officinalis (Jacq.) is the dominant wetland legume tree species of the seasonally flooded swamp forests in Guadeloupe, Lesser Antilles. This tree is periodically exposed to saline and flooded soil conditions. We examined mycorrhizal soil infectivity (most probable number (MPN) values) and arbuscular mycorrhizal (AM) colonization of $P$. officinalis along the salinity gradient where the salt levels ranged from 26 to $2 \%$ and from 22 to $5 \%$ at the end of the dry and wet season, respectively. MPN values were higher in the dry season than in the wet season. They decreased when the salt levels increased whatever the season. AM colonization of $P$. officinalis was well developed (up to 50\%) only within the low salinity levels (below 10\%) whatever the season. No spores were found in soil cores, suggesting that propagules were only mycelium pieces and/or root fragments of colonized Pterocarpus roots. These AM fungi may be adapted to salt stress and explain the maintenance of the high mycorrhizal inoculum potential in the $P$. officinalis swamp forest.
\end{abstract}

(C) 2006 Elsevier B.V. All rights reserved.

Keywords: Arbuscular mycorrhizal colonization; Swamp forest; Salinity; Flooding; Guadeloupe

\section{Introduction}

Arbuscular mycorrhizal fungi (AMF) in wetland habitats are exposed periodically to anaerobic soils and high soil salinity (Bohrer et al., 2004; Carvalho et al., 2004). Since AMF require oxygen to thrive, stressful environments regularly flooded with salt water may be detrimental for their survival and infectivity. Nevertheless, some AMF are able to persist in flooded soils and to colonize wetland plants (Khan, 1993; Miller and Bever, 1999; Turner et al., 2000; Landwehr et al., 2002). More than $50 \%$ of the plant's population were colonized by AMF in some wetlands conditions (Ragupathy et al., 1990). One species, Glomus geosporum, is usually dominant in European salt marshes (Landwehr et al., 2002; Carvalho et al., 2004). These studies suggest fungal adaptation to salt and flood conditions. In

\footnotetext{
* Corresponding author. Tel.: +33 380693032; fax: +33 380693262. E-mail address: christian.plenchette@dijon.inra.fr (C. Plenchette).
}

this respect, AMF possess propagules allowing long-term survival in soils and immediate opportunistic root colonization (Smith and Read, 1997). Spores, infected root fragments and extraradical mycelia are the main sources of inoculum potential in soils contributing to the infectivity of plants. The relative contribution of each type of propagules to plant root colonization is difficult to establish. Depending on fungal species, spore production and germination were affected by salinity and soil water levels (Miller and Bever, 1999; Carvalho et al., 2004). Le Tacon et al. (1986) reported that anaerobic conditions inhibited the germination of spores of Glomus mosseae, but that this effect was reversible upon exposure of the spores to air. The identity of the host plant was also known to be an important factor affecting density of AM propagules and sporulation (Smith and Read, 1997). However, extraradical mycelia and root fragments seemed to be relatively more important than spores for the initiation of plant colonization in wetlands, salt mashes and aquatic systems (Brown and Bledsoe, 1996; Carvalho et al., 2004). 
In the present work, we studied the AM inoculum potential in swamp soils from a monospecific stand of the wetland legume tree Pterocarpus officinalis. This tree is useful for the study of AM soil infectivity because it grows along a gradient of salinity. This allowed us also to determine the effect of salinity on AM colonization, while keeping the host plant constant.

\section{Materials and methods}

\subsection{Study site}

The Pterocarpus swamp forest covers 2600 ha of freshwater, coastal wetlands in Guadeloupe (Imbert et al., 2000). It is found mainly around the bay of the Grand cul-de-sac Marin, behind mangrove areas. The study site is located on the eastern side of the bay, in the Abymes coastal plain $\left(61^{\circ} 30^{\prime} \mathrm{N}, 16^{\circ} 10^{\prime} \mathrm{W}\right)$. At this site, the swamp forest is separated from the mangrove forest by a narrow strip (ca. $50 \mathrm{~m}$-wide) of mainly herbaceous vegetation, dominated by the fern Acrostichum danaefolium and the liana Rhabdadenia biflora. Some stunted Pterocarpus trees, mostly dead, occur inside this ecotope zone. From the swamp forest edge inwards, tree height gradually rises from about 5 to $20 \mathrm{~m}$ and over. As the canopy rises, stem density decreases, whereas basal area increases. P. officinalis is the only tree species contributing to the forest canopy. Understorey species, like Coccoloba venosa and Montrichardia arborescens, are few and far between. The forest is flooded most of the year, depending on the duration of the rainy season. Water level may vary from place to place, due to Pterocarpus buttresses that create low mounds. The soil is clayey, soft and brownish in the upper $30 \mathrm{~cm}$, denser and greyer below.

\subsection{Sampling and measurements}

The investigations were conducted along a transect starting from the seaward edge toward the inner part of the swamp forest. Sampling was made on three mature trees of $P$. officinalis in six plots $(3 \mathrm{~m} \times 3 \mathrm{~m})$ along a part of the transect that spanned an existing salinity gradient. The length of this part of the transect was approximately $170 \mathrm{~m}$. Water-table level was assessed around each sampled tree by measuring water depth in comparison with ground surface. Pore-water salinity at $20 \mathrm{~cm}$ below ground level and salinity of above-ground standing water were measured using an ATAGO ATC-S, temperature-compensated hand refractometer (ATAGO Inc.,
Bellevue, WA, USA). Salinity and water depth measurements were made at the end of the dry and wet season.

For each plot, five soil cores (20 cm in depth; $7 \mathrm{~cm}$ in diameter) were taken around each mature tree, pooled per soil salinity level and stored at room temperature $\left(20{ }^{\circ} \mathrm{C}\right)$. The method chosen for mycorrhizal soil infectivity determination was the most probable number (MPN) method (Porter, 1979). The method involves cultivation of a test plant having a high mycorrhizal dependency (Plenchette et al., 1983) on a range of successive dilutions of the soil to be tested. Soil samples were air dried and sieved $(2 \mathrm{~mm})$ prior to disinfect a sub sample of each by autoclaving $\left(115^{\circ} \mathrm{C}\right.$, $45 \mathrm{~min}$ ). The remaining humidity was determined. Then, for each sample, non-disinfected (ND) and disinfected (D) soils were mixed together to obtain the following range of dilutions: 1, 1/4, $1 / 16,1 / 64,1 / 256$ and 1/1024 (ND/D; w/w). Five replicates were made for each dilution. Soil $(100 \mathrm{~g})$ were placed in small pots then planted with a 2-week-old seedling of millet (Pennisetum americanum $\mathrm{L}$.) for a 6 -week growing period. Pots were placed in a controlled environment $\left(24{ }^{\circ} \mathrm{C}\right.$ day/ $18{ }^{\circ} \mathrm{C}$ night; relative humidity $80 \%$; light intensity $112 \mu \mathrm{mol} \mathrm{m} \mathrm{m}^{-2} \mathrm{~s}^{-1}$ ). After 6 weeks the entire root system of each plant was gently washed, cleared and stained (Phillips and Hayman, 1970). Observation of colonization was made under a dissecting microscope $50 \times$. One infection point was considered as sufficient to state that the plant was colonized. Calculation of MPN values were made as described by Sieverding (1991) according to Fisher and Yates (1948) and expressed per $100 \mathrm{~g}$ of dried soil.

The fine roots were randomly collected for each mature tree of $P$. officinalis (three replicates per tree), gently washed, cleared and stained (Phillips and Hayman, 1970). Roots were then cut into $1 \mathrm{~cm}$ pieces, mixed and placed on slides for microscopic observations at $250 \times$ magnification (Brundrett et al., 1985). One hundred root pieces were observed per plant. The extent of AM colonization was expressed as a percentage of the number of mycorrhizal root pieces/number of nonmycorrhizal root pieces. Data of mycorrhizal colonization were subjected to one-way analysis of variance, and mean values were compared using Newman-Keuls multiple range tests (Gagnon et al., 1989). Data of mycorrhizal colonization were transformed by arcsin (square root) before analysis.

\section{Results}

The salinity gradient ranged from 26 to $2 \%$ and from 22 to $5 \%$ at the end of the dry and wet season, respectively (Tables 1

Table 1

Soil salinity, mycorrhizal soil infectivity (MPN and confident limits) and mycorrhizal colonization of $P$. officinalis at the end of the dry season

\begin{tabular}{|c|c|c|c|c|c|}
\hline Plots & Salinity \%o $(0-20 \mathrm{~cm})$ & Water depth $(\mathrm{cm})$ & $\mathrm{MPN}^{*}(100 \mathrm{~g})$ & Confident limits $p<0.05$ & Colonization $^{* *}(\%)$ \\
\hline 1 & 26 & 4 & $75 \mathrm{a}$ & $35-160$ & $14.5 \mathrm{a}$ \\
\hline 2 & 20 & 3 & $150 \mathrm{a}$ & $70-320$ & $29.4 \mathrm{~b}$ \\
\hline 3 & 15.5 & 21 & $560 \mathrm{~b}$ & $262-1196$ & $47.5 \mathrm{c}$ \\
\hline 4 & 10 & -12 & $2400 \mathrm{bc}$ & $1123-5126$ & $66.0 \mathrm{~d}$ \\
\hline 5 & 3 & -3 & $3402 \mathrm{c}$ & $1592-7266$ & $76.9 \mathrm{e}$ \\
\hline 6 & 2 & -7 & $3800 \mathrm{c}$ & $1779-8166$ & $82.8 \mathrm{e}$ \\
\hline
\end{tabular}

\footnotetext{
* Values followed by the same letters are not significantly different (confident limits, $p<0.05$ ).

** Values followed by the same letters are not significantly different (Newman-Keuls, $p<0.05$ ).
} 
Table 2

Soil salinity, mycorrhizal soil infectivity (MPN and confident limits) and mycorrhizal colonization of $P$. officinalis at the end of the wet season

\begin{tabular}{|c|c|c|c|c|c|}
\hline Plots & Salinity $(\% o)(0-20 \mathrm{~cm})$ & Water depth $(\mathrm{cm})$ & $\mathrm{MPN}^{*}(100 \mathrm{~g})$ & Confident limits $p<0.05$ & Colonization $^{* *}(\%)$ \\
\hline 1 & 22 & 16 & $20 \mathrm{a}$ & $9-42$ & $22.1 \mathrm{a}$ \\
\hline 2 & 15 & 15 & $31 \mathrm{a}$ & $15-67$ & $40.3 \mathrm{~b}$ \\
\hline 3 & 13.5 & 33 & $90 \mathrm{bc}$ & $42-191$ & $48.8 \mathrm{~b}$ \\
\hline 4 & 8 & 0 & $1157 \mathrm{~d}$ & $542-2472$ & $65.1 \mathrm{c}$ \\
\hline 5 & 3 & 9 & $688 \mathrm{~d}$ & $322-1469$ & $68.9 \mathrm{c}$ \\
\hline 6 & 5 & 5 & $301 \mathrm{~cd}$ & $141-644$ & $75.1 \mathrm{c}$ \\
\hline
\end{tabular}

* Values followed by the same letters are not significantly different (confident limits, $p<0.05$ ).

** Values followed by the same letters are not significantly different (Newman-Keuls, $p<0.05$ ).

Table 3

Correlation coefficients ( $r$ ) between mycorrhizal soil infectivity (MPN values), soil salinity ( $\mathrm{S} \%$ ) and mycorrhizal colonization of roots (\% AM colonization)

\begin{tabular}{|c|c|c|c|c|c|c|}
\hline & \multicolumn{3}{|c|}{ Dry season } & \multicolumn{3}{|c|}{ Wet season } \\
\hline & MPN & $S$ & $\mathrm{AM}(\%)$ & MPN & $S$ & $\mathrm{AM}(\%)$ \\
\hline $\begin{array}{l}\text { MPN } \\
\text { S }\end{array}$ & & $-0.96^{*}$ & $\begin{array}{r}0.95^{*} \\
-0.99^{*}\end{array}$ & & $-0.86^{*}$ & $\begin{array}{r}0.75^{*} \\
-0.97^{*}\end{array}$ \\
\hline
\end{tabular}

* Significant $(p<0.05)$.

and 2). There was not an evident flooding gradient in wet and dry seasons in the $P$. officinalis swamp forest (Tables 1 and 2).

Spores were not found in the soil samples collected during the dry and wet seasons (Tables 1 and 2). Nevertheless, AMF were present in the root samples of $P$. officinalis, whatever the salt level (Tables 1 and 2). The higher AM colonization (82-75\%) was recorded for the lowest salt level (2-5\%) (Tables 1 and 2). AM colonization was greater to $50 \%$ until the salt levels of 8 and $10 \%$ were reached in wet and dry seasons, respectively. MPN values due to mycelium and root fragments also decreased as salt level increased (Tables 1 and 2). However, MPN values were higher in the dry season than in the wet season.

Significant negative correlations were obtained between the salt levels and the MPN values both in wet and dry seasons (Table 3). MPN values and AMF colonization were positively correlated in dry season (Table 3). Whatever the season, colonization percentage was negatively correlated with salinity level (Table 3, Fig. 1).

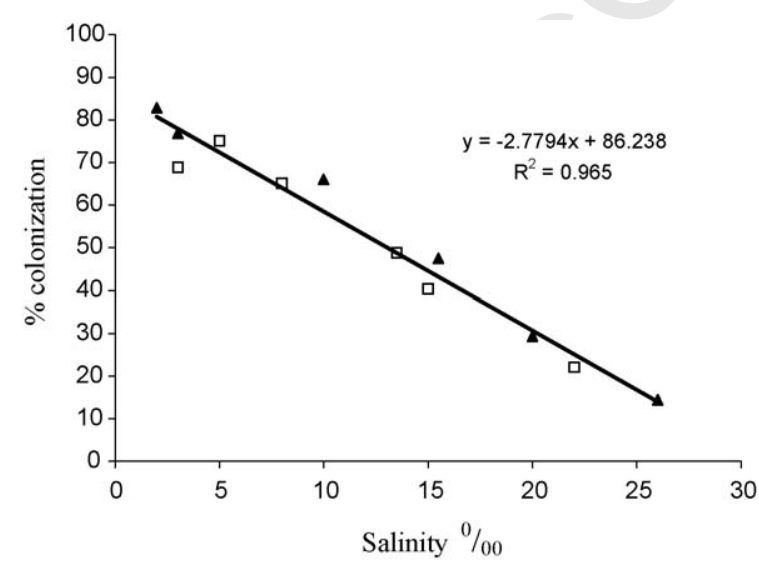

Fig. 1. Relationship between salinity level and development of AM colonization. ( $\square$ ) Dry season; ( $\mathbf{\Delta})$ wet season.

\section{Discussion}

Salinity has been shown to be an important factor influencing AM colonization of $P$. officinalis and fungal inoculum potential in swamp soils. AM colonization was indicated by the presence of aseptate hyphal coils and vesicles as Paris-type mycorrhizas (Bâ et al., 2004). Surprisingly, no spores were found in sieved soil samples collected during the dry and wet seasons. Since spores were absent, we conclude that the infection units and colonization of roots were due to mycelium and/or root fragments. We do not know the relative proportion of infection units and AM colonization derived from mycelium or root fragments. Furthermore, it is not clear whether the absence of spores in swamp soils was due to the toxic levels of minerals and/or to variations of depth water in dry and wet seasons. Some studies indicate that water depth is an important factor determining the distribution of spore species along a dry to wet gradient (Miller and Bever, 1999). The overall trend was for fewer spore species in wetter sites than in drier sites. Other studies suggest that soils from salt marshes contain spores of AMF in high numbers, whereas reduction of spore germination at water levels above field capacity may be related to the low tolerance of AMF to hypoxic conditions (Landwehr et al., 2002; Carvalho et al., 2004).

We found evidence for potential adaptation of native AMF to salt swamp soils and for the ability of AM propagules to spread into the roots. Indeed, AMF colonization was greater to $50 \%$ until the salt level of $8 \%$ was reached in dry and wet seasons and decreased in both seasons as salt level increased. Since AM colonization was already recorded on wetlands plants (Bohrer et al., 2004), some results were unexpected at very high salinity levels (Brown and Bledsoe, 1996). Our results suggest that AMF were well adapted to stressful salt swamp soils. The absence of spore in sieved swamp soils did not permit conclusions as to the taxonomy of these AMF. PCR with taxonspecific primers have been used to identify AMF within colonized roots (Landwehr et al., 2002). We plan to incorporate such techniques in our future work.

AM colonization did not vary significantly from wet to dry season, whereas the MPN values did. One possible explanation is that fungi may endure prolonged exposure to salt and flooding by spreading inside the Pterocarpus roots, whereas extraradical mycelium and root fragments in soils may not. In this respect, roots of $P$. officinalis would be well aerated due to aerenchymatous tissue, adventive roots and buttress lenticels. 
Brown and Bledsoe (1996) observed AMF in the aerenchymatous tissue of salt marsh plants, suggesting that AMF are adapted to life in oxygen-deficient soils. MPN values were mainly higher than those recorded in other tropical soils, i.e., 10 propagules $/ 100 \mathrm{~g}$ for a lowland wet forest in Costa Rica (Fisher et al., 1994) or 1-100 propagules/100 g for soils used for intensive banana cultivation in Martinique (Declerck et al., 1999). This suggests that $P$. officinalis may be considered as a high mycorrhizal dependent tree which favor AM fungal development. The high mycorrhizal soil infectivity could be also a real potential for the traditional culture of taro in the Pterocarpus swamp forests (Saur and Imbert, 2003). From an ecological point of view, AM soil infectivity and seasonal dynamics of AM colonization should be considered further to better assess the role and the distribution of AMF in the Pterocarpus swamp forests.

\section{Acknowledgements}

We thank the GIS ECOFOR and the Ministère de l'Ecologie et du Développement Durable (grant no. 020000118) for their financial support. We thank also A. Rousteau and N. Tromas for their help during the sampling.

\section{References}

Bâ, A.M., Samba, R., Sylla, S.N., Le Roux, C., Neyra, M., Rousteau, A., Imbert, D., Toribio, A., 2004. Caractérisation de la diversité des microorganismes symbiotiques de Pterocarpus officinalis dans des forêts marécageuses de Guadeloupe et de Martinique. Rev. Ecol. 59, 163-170.

Bohrer, E.K., Friese, C.F., Amon, J.P., 2004. Seasonal dynamic of arbuscular mycorrhizal fungi in differing wetland habitats. Mycorrhiza 14, 329-337.

Brown, A.M., Bledsoe, C., 1996. Spatial and temporal dynamics of mycorrhizas in Jaumea carnosa, a tidal saltmarsh halophyte. J. Ecol. 84, 703-715.

Brundrett, M.C., Piche, Y., Peterson, R.L., 1985. A developmental study of the early stages in vesicular-arbuscular mycorrhizal formation. Can. J. Bot. 63, 184-194.

Carvalho, L.M., Correia, P.M., Martins-Louçao, A., 2004. Arbuscular mycorrhizal fungal propagules in a salt mash. Mycorrhiza 14, 165-170.
Declerck, S., Plenchettet, C., Risede, J. M., Strullu, D. G., Delvaux. B., 1999. Estimation of the population density of arbuscular mycorrhizal fungi in soils used for intensive banana cultivation in Martinique fruits. 54, 3-9.

Fisher, R.A., Yates, F., 1948. Statistical Tables for Biological Agriculture and Medical Research, sixth ed. Hafner Publ. Comp., Davien.

Fisher, C.R., Janos, D.P., Perry, D.A., Linderman, R.G., 1994. Mycorrhiza inoculum potentials in tropical secondary succession. Biotropica 26, 369-377.

Gagnon, J., Haycock, K.A., Roth, J.M., Feldman, D.S., Finzer, W.F., 1989. Abacus Concepts SuperAnova: Les Modèles Linéaires Généralisés. Abacus concepts, Inc., Berkeley, CA, USA.

Imbert, D., Bonhême, I., Saur, E., Bouchon, C., 2000. Floristics and structure of the Pterocarpus officinalis swamp forest in Guadeloupe, Lesser Antilles. J. Trop. Ecol. 16, 55-68.

Khan, A.G., 1993. Occurrence and importance of mycorrhizae in aquatic trees of New South Wales, Australia. Mycorrhiza 3, 31-38.

Landwehr, M., Hildebrandt, U., Wilde, P., Nawrath, K., Toth, T., Biro, B., Bothe, H., 2002. The arbuscular mycorrhizal fungus Glomus geosporum in European saline, sodic and gypsum soils. Mycorrhiza 12, 199-211.

Le Tacon, F., Skinner, F.A., Mosse, B., 1986. Spore germination and hyphal growth of a vesicular-arbuscular mycorrhizal fungus Glomus mosseae (Gerdemann and Trappe) under decreased oxygen and increased carbon dioxide concentrations. Can. J. Bot. 29, 1280-1285.

Miller, S.P., Bever, J.D., 1999. Distribution of arbuscular mycorrhizal fungi in stands of the wetland grass Panicum hemitomon along a wide hydrologic gradient. Oecologia 119, 586-592.

Phillips, J.M., Hayman, D.S., 1970. Improved procedures for clearing roots and staining parasitic and vesicular-arbuscular mycorrhizal fungi for rapid assessment of infection. Trans. Br. Mycol. Soc. 55, 158-161.

Plenchette, C., Fortin, J.A., Furlan, V., 1983. Growth responses of several plant species to mycorrhizae in a soil of moderate P-fertility. I: Mycorrhizal dependency under field conditions. Can. J. Bot. 70, 199-209.

Porter, W.M., 1979. The most probable number method for numerating infective propagules of vesicular arbuscular mycorhizal fungi in soil. Aust. J. Soil Res. 17, 515-519.

Ragupathy, S., Mohankumar, V., Mahadevan, A., 1990. Occurrence of vesicular-arbuscular mycorrhizae in tropical hydrophytes. Aquat. Bot. 36, $287-$ 291.

Saur, E., Imbert, D., 2003. Traditional monoculture of taro (Colocasia esculenta) in the swamp forest of Guadeloupe West Indies. Bois For. Trop. 277 (3), 85-89.

Sieverding, E., 1991. Vesicular-arbuscular Mycorrhiza Management in Tropical Agrosystems. GTZ, Germany, $371 \mathrm{pp}$.

Smith, S.E., Read, D.J. (Eds.), 1997. Mycorrhizal Symbiosis. second ed. Academic Press, San Diego, London.

Turner, S.T., Amon, J.P., Schneble, R.M., Friese, C.F., 2000. Mycorrhizal fungi associated with plants in ground-water fed wetlands. Wetlands 20, 200-204. 